Ophthalmic Res. 1988;20:121-124

\title{
Contents, Vol. 20, No. 3, 1988
}

\section{Contents}

Preface125

Studies on the Molecular Organization of the Lens

Farnsworth, P.N.; Schleich, T.W.; Groth-Vaselli, B.; Kuckel, C.L 126

Pharmacologic Blockade of Ionic Channels in Lens Membranes

Rae,J.L $\quad 132$

Characterization of the Equatorial Current of the Lens

Patterson, J.W 139

Accelerated Heavy Particles and the Lens.

V. Theoretical Basis of Cataract Enhancement by Dose Fractionation

Worgul,B.V 143

Relation of the Depth of the Anterior Chamber to the Lens Thickness: Clinical Significance

Olbert, D 149

In vivo Observation of the Crystalline Lens Capsule

Sasaki, K.; Kojima, M; Hara, T 154

Tissue Plasminogen Activator in the Lens

Tripathi, B.J.; Tripathi, R.C.; Geanon, J.D 160

Ascorbic Acid and the Eye Lens

Varma, S.D.; Richards, R.D 164

Alterations of Lens Metabolism with Experimentally Induced Cataract in Rats

Korte, I.; Hockwin, O.; Bours, J.; Wegener, A 174

Long-Term Visual Health Risks from Solar Ultraviolet Radiation. Proposals for Ocular

Protection

Waxier, M 179

Lens Alpha-Neoproteins

Manski, W.; Malinowski, K 183

Effect of Glutathione Depletion on Cation Transport and Matabolism in the Rabbit Lens

Reddy, V.N.; Garadi, R.; Chakrapani, B.; Giblin, F.J 191

Lens Membrane Properties Following Hydrogen Peroxide Exposure

Delamere, N.A.; Paterson, C.A.; Hensley, S 200

Announcement 204 